\title{
Otology practice in a Nigerian tertiary health institution: A 10-year review
}

\author{
Page $\mid 218 \quad$ A. D. Salisu \\ Department of Otorhinolaryngology, Bayero University/Aminu Kano Teaching Hospital, Kano, Nigeria
}

Correspondence to: Dr. Abubakar Salisu, Department of Otorhinolaryngology, Aminu Kano Teaching Hospital, Kano, Nigeria. E-mail: adsalisu@yahoo.com

\begin{abstract}
Background:The practice of otology in developing countries has remained unsatisfactory. The aim of this study is to describe the practice in a tertiary health institution with a view to articulate strategies for improvement.

Materials and Method: This a retrospective study of patients with otology problems, who attended Ear, Nose and Throat clinic of Aminu Kano Teaching Hospital, Kano, over a 10-year period (1997-2007). Case notes were retrieved and studied.

Results: Otologic conditions accounted for $56.3 \%$ of the 8070 clinic visits. The most frequent condition seen was chronic otitis media (25.4\%). Sensorineural hearing loss (mostly preventable) accounted for $16 \%$. Other cases included wax impaction (7.5\%) and foreign body in ear (7.3\%). Modern diagnostic and operative equipment were lacking. Operative surgery was offered to $4 \%$ of cases of chronic suppurative otitis media and $72 \%$ of patients needing hearing aid could not afford one. There was no middle ear reconstructive or inner ear operation in the 10-year period. Conclusion: A significant number of patients are in need of otology services. These services are inadequate presently. Concerted effort should be geared toward strengthening preventive ear health, training and re-training, procurement of relevant diagnostic and operative equipment.
\end{abstract}

Keywords: Developing countries, Otology practice

\section{Résumé}

Arrière-plan: La pratique du otologie dans les pays en développement est resté insatisfaisante. L'objectif de cette étude est de décrire la pratique dans un établissement de santé tertiaires en vue de stratégies articulées pour amélioration. Matériaux et de la méthode: Cette étude une rétrospective des patients souffrant de problèmes d'otologie, qui ont participé aux oreilles, nez et gorge clinique de Aminu Kano enseignement Hospital, Kano, sur une période de 10 ans (1997-2007). Notes de cas ont été récupérés et étudiés.

Résultats: Otologic conditions représentaient $56.3 \%$ des visites 8070 clinique. La condition plus fréquente vue était otite chronique (25,4\%). Une perte auditive neurosensorielle (principalement évitable) représentait 16\%. Autres cas inclus cire impaction (7,5\%) et un corps étranger dans l'oreille (7,3\%). Équipement moderne de diagnostic et dispositif manquaient. Chirurgie du dispositif a été offerte à $4 \%$ des cas de chronique suppurative otite et $72 \%$ des patients qui ont besoin de la prothèse auditive ne pouvaient se permettre un. Il n'y n'avait aucune oreille moyenne reconstructive ou l'oreille interne opération pendant l'année de 10 période.

Conclusion: Un important nombre de patients ont besoin de services d'otologie. Ces services sont actuellement insuffisants. Effort concerté doit être orienté vers le renforcement de santé préventive d'oreille, de formation et de recyclage, approvisionnement de pertinentes diagnostic et dispositif matériel.

Mots-clés: Pays en développement, pratique otologie

\section{Introduction}

The subspecialty of otology is capital intensive with regard to setting up and providing postgraduate training. Patient attendance at ENT clinics with otologic complaints is significantly high. Okafor 
and Bhatia et al in separate reports have attributed otologic problems to account for between 54 and $60 \%$ of all ENT clinic attendance at Enugu and Jos, respectively. ${ }^{[1,2]}$

The practice of otology in developing countries has remained unsatisfactory. ${ }^{[3]}$ In a 15 -year review of otologic surgery in a tertiary institution, Lasisi et al observed that few mastoidectomy operations (5\%) were carried out on chronic otitis media patients who had indications for the surgery and residents in training performed only $5 \%$ of the operations. ${ }^{[3]}$ No such review has been reported from northern Nigeria.

The needs of the otology subspecialty should be identified in order to formulate a deliberate policy that will put this important subspecialty on a proper footing. Budgetary allocation of resources, manpower training needs and research priorities will depend on local disease pattern.

The aim of this study is to describe the pattern of otology practice over a 10 -year period in Aminu Kano Teaching Hospital in northern Nigeria. We hope that an understanding of the pattern of otology disease in our environment from this retrospective study would allow us formulate policies and programs that will improve the clinical practice of otology in developing countries.

\section{Materials and Methods}

This is a retrospective study of patients with otologic problems, who attended the otorhinolaryngological clinic (ENT) of Aminu Kano Teaching Hospital, Kano, over a 10-year period (1997-2007). Case notes were retrieved and studied. Patient's age, sex, diagnosis, audiometric assessment, radiologic and computed tomographic (CT) scan requests were retrieved using a standard proforma. Any outpatient or theater surgical procedure was also noted. Data collected were analyzed by simple descriptive method.

\section{Results}

A total of 8070 clinic attendance was noted over the period, out of which 4541 (56.27\%) was for otologic condition. The otologic attendance consisted of 2556 males and 1985 females, giving a sex ratio of 1.3:1. Age ranged from 4 weeks to 72 years with $33.4 \%$ of patients below 10 years [Table 1 ].

The most frequent otologic conditions included chronic suppurative otitis media (CSOM) 25.4\%, sensorineural hearing loss (SNHL) 16\% and wax impaction/foreign body (FB) in the ear $14.8 \%$ [Table 2]. Exactly 2709 pure tone audiograms (PTA) and 2383 tympanograms were obtained. Hearing aid evaluation revealed benefit for 901 patients, of whom $250(27.7 \%)$ were able to afford. Also, 52 X-ray mastoids were done. Seven cases had CT scan done. There were 542 outpatient procedures with FB extraction from the ear being the most common (58\%), followed by ear syringing [Table 3]. A total of 103 otologic operations were carried out in the theater, with external ear operations constituting $76 \%$ of the operations and middle ear operations $24 \%$. No surgery was carried out for inner ear related pathology [Table 4].

\section{Discussion}

Otologic problems were the most commonly seen

\begin{tabular}{lcc}
\hline \multicolumn{3}{l}{$\begin{array}{l}\text { Table 1: Age range of patients presenting with } \\
\text { otologic disease }\end{array}$} \\
\hline Age range (years) & No. cases & $\%$ \\
\hline $0-9$ & 1516 & 33.4 \\
$10-19$ & 701 & 15.44 \\
$20-29$ & 1046 & 23 \\
$30-39$ & 647 & 14.3 \\
$40-49$ & 351 & 7.73 \\
$50-59$ & 163 & 3.6 \\
$60-69$ & 102 & 2.25 \\
$\geq 70$ & 15 & 0.33 \\
Total & 4541 & 100 \\
\hline
\end{tabular}

\begin{tabular}{lcc}
\hline \multicolumn{3}{l}{ Table 2: Ten most frequently seen ear diseases } \\
\hline Ear disease & $\begin{array}{c}\text { No. of } \\
\text { cases }\end{array}$ & $\%$ \\
& 1154 & 25.4 \\
\hline CSOM & 728 & 16 \\
SNHL & 339 & 7.5 \\
Wax impaction & 331 & 7.3 \\
Foreign body in ear & 262 & 5.8 \\
Tinnitus & 231 & 5 \\
Acute Suppurative & & \\
Otitis Media (ASOM) & 181 & 4 \\
Ossicular disease & 150 & 3.3 \\
Eustachian dysfunction & 79 & 1.7 \\
Otitis Media with & & \\
Effusion (OME) & 66 & 1.5 \\
Tumor (external/middle ear) & 66 \\
\hline
\end{tabular}

\begin{tabular}{lcc}
\hline \multicolumn{3}{l}{ Table 3: Outpatient otologic procedures } \\
\hline Procedure & No. done & $\%$ (approx) \\
\hline Foreign body extraction & 314 & 58 \\
Ear syringing for & 129 & 23.8 \\
wax, otomycosis & & \\
Excision biopsy & 54 & 10 \\
I and D preauricular abscess & 19 & 3.5 \\
Keloid excision & 6 & 1.1 \\
I and D mastoid abscess & 5 & 0.9 \\
Total & 542 & 100.0 \\
\hline
\end{tabular}




\begin{tabular}{lcc}
\hline \multicolumn{3}{l}{ Table 4: Surgical procedures in theatre } \\
\hline Procedure & No. done & \% (approx) \\
\hline Foreign body extraction & 17 & 16.5 \\
Keloid excision & 14 & 13.6 \\
Aural polyp excision & 13 & 12.6 \\
Preauricular sinus excision & 12 & 11.7 \\
Modified radmastoidectomy & 11 & 10.7 \\
Pinna repair & 8 & 7.8 \\
Transcanal biopsy & 6 & 5.8 \\
Myringotomy & 6 & 5.8 \\
Meatoplasty & 4 & 3.9 \\
Tympanoplasty & 3 & 2.9 \\
Others & 9 & \\
Total & 103 & \\
\hline
\end{tabular}

problems in the general ENT clinic from this study, accounting for $56.3 \%$ of consultations. This has also been observed by Okafor in Enugu and Bhatia et al in Jos. ${ }^{[1,2]}$ The importance of otology as a subspecialty therefore cannot be overemphasized.

The most common disease seen was CSOM (25.4\%); majority of the cases (96\%) were of tubotympanic variety which commonly starts during childhood. This was similar to findings of Okafor at Enugu, where he reported that CSOM constituted $44.8 \%$ of otologic workload and $99 \%$ of cases were of tubo-tympanic variety. ${ }^{[1]}$

Chronic otitis media is a preventable disease and many studies have blamed poor socioeconomic factors for its high prevalence. ${ }^{[4]}$ The microbiology of the ear discharge revealed predominantly Pseudomonas aeruginosa, Staphylococcus aureus and Proteus mirabilis, occurring either as pure cultures or in combination. ${ }^{[5]}$ This bacteriology is similar to findings in southern Nigeria. ${ }^{[6]}$ The patients were generally managed conservatively and surgery was reserved for complications which were seen in $4 \%$ of cases. These complications included mastoid abscess, cholesteatoma and aural polyp. Similarly, other studies also found that the main indications for middle ear surgery in developing countries were complications of CSOM. ${ }^{[7,8]}$ A few cases (3) had myringoplasty to close up the perforated tympanic membrane; otherwise, no reconstructive middle ear surgery was performed. The paucity of middle ear operations was also reported by Lasisi et al..$^{[3]}$ This may have been due to inadequate training, absence of operating microscope/ear microsurgical instruments and fewer cases of cholesteatomatous ears, compared to other populations. ${ }^{[9]}$ It is of note that hammer and gouge are still commonly employed for bone work in developing countries.

These limitations have a profound effect on training and skill acquisition. In an audit of specialist registrars in tympanomastoid surgical training, Mahendran et al found that high degree of exposure of trainees corroborated well with successful surgical outcome. ${ }^{[10]}$

Sensorineural hearing loss (SNHL) was the second most frequent disease (16\%), with bacterial meningitis being responsible for majority of cases. Ototoxicity and use of traditional concoctions were found to be frequent causes of SNHL. These are all preventable, especially, at the primary health care level. In most cases, pure tone audiologic assessment showed bilateral severe to profound hearing loss affecting all frequencies. Majority of cases did not recover hearing.

Facilities for otoacoustic emission and brainstem evoked response audiometry (BERA) for screening were unavailable. The patients were generally advised to try hearing aid. Of the patients assessed to benefit from a hearing aid, only $27 \%$ were able to procure one. Reasons for lack of procurement included financial handicap, denial of need and widely held belief that hearing aid perpetuates or worsens hearing loss.

Many of those using hearing aid were found to discontinue its use after sometime, blaming equipment damage, lack of benefit in noisy places and lack of service/maintenance points locally.

Wax (7.5\%) and FB impaction in the ear (7.3\%) were found to be common; these cases are usually successfully managed. Okafor noted that FB in ear accounted for $12 \%$ of otologic consultations. ${ }^{[1]}$ The major problems associated with these conditions were attempted extraction/syringing at home or peripheral health facility in which case patients tend to come with external ear trauma, tympanic membrane perforation, ossicular damage and otitis media. Okafor found $82 \%$ of ear trauma to be related to this practice. ${ }^{[1]}$ Dangers of unskilled attempts at extraction of FB from the ear have been well documented. ${ }^{[11,12]}$

It appeared from the study that inadequate quality consultation time was given to tinnitus and vertigo sufferers who accounted for nearly $6 \%$ of the patients seen in the period under review.

In-depth assessment of these patients was lacking as all patients were seen in general otorhinolaryngology clinic and not in specialized clinics. Factors responsible for this may have included poor understanding of these conditions by the practicing otolaryngologist, large patient population in the clinic, lack of sub-specialist and lack of diagnostic tools such as electrocochleography, electronystagmography and vestibular evoked myogenic potentials. ${ }^{[13]}$ 
Inaccessibility of these and other diagnostic tools such as CT scan and magnetic resonance imaging (MRI) greatly hampered the in-depth assessment and operative planning of patients with otologic and neuro-otologic tumors which constituted about $1.5 \%$ of patients seen during the period. The importance of CT scan and MRI in neuro-otology cannot be overemphasized. ${ }^{[14,15]}$

These factors may also have been responsible for the total absence of inner ear operations during the period under review.

\section{Conclusion}

The practice of otology was unsatisfactory despite a high demand for otologic services. To improve the practice and achieve better ear care, it is the view of the author that: (1) preventive ear health should be strengthened by a combination of health education drive and immunization especially for meningitis; (2) local assembly/manufacture/servicing of hearing aid should be considered; (3) a proactive approach should be employed for acquisition of relevant diagnostic and operative equipment and (4) functional temporal bone laboratory should be established in training institutions.

\section{References}

1. Okafor BC. Otolaryngology diseases in South Eastern Nigeria: Pattern of diseases of the ear. Niger Med ] 1983;13:11-9.

2. Bhatia PL, Varughese R. Pattern of otolaryngological diseases in Jos community. Niger Med ] 1987; 17:67-73.

3. Lasisi OA, Nwaorgu OG, Garndawa HI, Isa A. A fifteen year review of otologic surgery in Ibadan, Nigeria: Problems and prospects. Niger ] Surg Res 2002;4:45-9.

4. Ologe FE, Nwawolo CC. Chronic suppurative otitis media in school pupils in Nigeria. East Afr Med ] 2003;80:130-4.

5. Nwankwo EO, Salisu AD. Bacteriology of chronic discharging ears of patients in Kano, Nigeria. J Med Lab Sci 2005;14:57-62.

6. Coker OA, Ijaduola GT, Odugbemi TO. Bacterial isolates from chronic discharging ears in Nigerian children. Niger Med Pract 1982; 4:170-4.

7. Okafor BC. The chronic discharging ear in Nigeria. ] Laryngol Otol 1984;98:113-9.

8. Brobby GW. The discharging ear in the tropics: A guide to diagnosis and management in the district hospital. Trop Doct 1992;22:10-3.

9. Rothstein ], Haezlewood R, Fraser M. Health of aboriginal and torres strit islander children in remote far north Queensland: Findings of paediatric outreach service. Med ] Aust 2007;186:519-21.

10. Mahendran S, Benett AN, Jones SE, Young BA, Prinsley PR. Audit of specialist registrar training in tympanomastoid surgery for chronic otitis media. ] Laryngol Otol 2006;120:193-9.

11. Ladapo AA. Danger of foreign bodies in the ear. Niger Med ] 1984;9:120-2.

12. Ogunleye AO, Awobem AA. Trends of ear syringing at Ibadan, Nigeria. Afr ] Med Med Sci 2004;33:35-7.

13. Lin MY, Timmer FC, Oriel BS, Zhou G, Guinan J], Kujawa $\mathrm{SG}$, et al. Vestibular evoked myogenic potentials (VEMP) can detect asymptomatic saccular hydrops. Laryngoscope 2006;116:987-92.

14. Gunlock MG, Gentry LR. Anatomy of the temporal bone. Neuroimaging Clin N Am 1998;8:195-209.

15. Curtin HD, Hirsch WL Jr. Imaging of acoustic neuromas. Otolaryngol Clin North Am 1992;25:553-607.

Source of Support: Nil, Conflict of Interest: None declared. 